Maximising performance gains from cooperative marketing: understanding the role of environmental contexts

Sonia Dickinson (all correspondence)

School of Marketing

Curtin University of Technology

GPO Box U1987

PERTH WA 6845

Ph: (+61 8) 92663738 Fax: (+61 8) 92663937

Email: sonia.dickinson@cbs.curtin.edu.au

and

B Ramaseshan

School of Marketing

Curtin University of Technology

GPO Box U1987

PERTH WA 6845

Ph: (+61 8) 92664674 Fax: (+61 8) 92663937

Email: Ramaseshanb@cbs.curtin.edu.au 


\title{
Maximising performance gains from cooperative marketing: understanding the role of environmental contexts
}

\begin{abstract}
Cooperative marketing strategies have the potential to make an enduring contribution to business performance and are among the strategic responses that a firm could consider when faced with environmental challenges.
\end{abstract}

The focus of this study is to determine the effect of cooperative marketing strategies on organisational performance. Such organisational performance is investigated as being contingent on the use of cooperative marketing under given internal and external environmental contexts. That is, this study focuses on the performance outcomes associated with cooperative marketing strategies and attempts to identify environmental contexts under which cooperative marketing strategies are best implemented.

Based on empirical analysis, results indicate that the higher the incidence of cooperative marketing strategy implementation, the higher perceived alliance performance outcomes. The perceived alliance performance benefits however were increased in given environmental contexts. Performance was positive as a result of co-marketing where there were regional and industry factors at play. That is, performance outcomes resulted when there were higher levels of co-marketing and when there was good quality infrastructure and under industry conditions when there was high entry requirements, 
high competitive intensity and high levels of environmental capacity. Managerial implications and future directions for research are also provided in the paper. 


\section{BIOGRAPHY}

Sonia Dickinson is a Lecturer in the School of Marketing, Curtin University of Technology, Perth, Western Australia. Sonia lectures in undergraduate and postgraduate marketing courses and is the Director of the Social Marketing Research Unit. Sonia has a keen interest in non-profit marketing and social marketing issues. Other research interests include cooperative marketing, branding, and marketing communications.

B (Ram) Ramaseshan is Professor of Marketing and Head of the School of Marketing at Curtin University of Technology, Perth, Western Australia. Professor Ramaseshan teaches marketing, marketing strategy and business research methods. His research interests are in the areas of marketing strategy formulation and implementation, export barriers, international business alliances, and international marketing channels. 


\section{INTRODUCTION}

In an effort to deal with environmental contexts, firms make strategic decisions unique to their operating situation. Universally, firms seek to gain competitive advantage and achieve performance though strategic decision making that achieves a fit between strategies and environmental conditions.

While there are numerous strategy solutions that can contribute to positive performance outcomes, cooperative marketing is one such strategy that firms can consider in response to environmental demands. Cooperative marketing is a type of interorganisational arrangement (IOA) that is appealing to organisations as they are an alternative to internal development, mergers and acquisitions, each of which lack environmental responsiveness and require great financial investment. IOA's are beneficial as they enable businesses to achieve higher levels of product innovation, can assist expansion into new markets and customer segments, and can broaden product ranges, with minimal financial investment (Maynard 1996).

While there is a spectrum of IOA's that can provide a firm with potential performance outcomes (such as contractual arrangements, strategic alliances, joint ventures and consortia), commonalities between IOA's include; interdependency among firms; firms enter into deliberate relationships for the joint accomplishment of goals; and firms aim to reduce resource, skill, and knowledge weaknesses (Pisano, Russo \& Teece 1988; Terpstra \& Simonin 1992). This study focuses on cooperative marketing which is a functional 
IOA and is a form of strategic alliance. Cooperative marketing occurs when companies cooperate in terms of marketing so that they move beyond transactional arrangements, towards the development of relationships. Each organisation, of which there are at least two, arrange their resources and programs in an alliance, which is designed to improve the marketing potential of each participant. Firms that enter into cooperative marketing arrangements can cooperate with actual or potential competitors across marketing mix elements such as products, promotions, distribution and pricing efforts. Co-marketing occurs when there is pooling or trading of marketing resources is used across marketing mix elements of, product, pricing, promotion, and distribution. Beyond the basic marketing mix elements of cooperation, arrangements can extend to cooperative product/service design, product bundling, joint service offers for warranty, joint maintenance, repair and technical assistance. Furthermore, cooperation across marketing activities such as warehousing and inventory control, physical distribution, cooperative sales promotion and cooperative packaging, branding, positioning, and repackaging, also account for cooperative marketing strategies (Arndt 1979; Buttery \& Buttery 1998; Anderson \& Narus 1991; Varadarajan \& Rajaratnam 1986).

By understanding the appropriateness of cooperative marketing strategy implementation under various contexts, firms can equip themselves with a new mindset relating to cooperation and the achievement of performance outcomes. This research focuses specifically on the performance implications of cooperative marketing strategy implementation. Within the field of research, there is a need to move beyond a basic understanding of why firms cooperate, and instead shift towards normative descriptions of fitting contexts for cooperation, and the performance implications of such cooperation. 
This study is important as it addresses these key issues. That is, this study focuses on lateral cooperative arrangements, which are specific to the field of marketing. The research responds to the need for conceptual development, as well as empirical results to provide testimony of hypothesised relationships. The value of empirical links between cooperative marketing strategy use and performance outcomes cannot be overlooked, considering that such information has not been collected to date.

(1) The third link - Performance and cooperative strategy implementation - As indicated in the multiple regression analysis, performance is positively linked with higher levels of cooperative marketing strategy implementation. Further testimony to this 'third link' is supported by Cluster and Discriminant analysis whereby the highest performance cluster had the highest level of cooperative marketing strategy implementation. The reverse was found for the lowest performance cluster. These findings are significant for several stakeholders. Academics, and businesses together with government agencies are provided with confirmation of positive performance resulting from cooperative marketing. As mentioned above, this has implications for resource allocations and attenuating business success through cooperative strategies.

(2) Determination of an the "ideal cooperative marketing profile - Beyond general descriptives such as industry group, firm size and export/non export status, Cluster and Discriminant analysis has resulted in an understanding of 'who' cooperates, and their associated performance outcomes. An 'ideal cooperator' profile is determined. Firms who are highly cooperative and who are successful as a result of this cooperation exhibit 
distinctive characteristics or 'profiles'. Ascertaining this profile, should enable academics to channel future research more directly to those firms within the specified profiles, and secondly, enable practitioners with these characteristics to have more confidence in their cooperative marketing decisions. Government funding allocations can also be more specifically channelled to firms with "ideal profiles", who are more likely to achieve positive performance outcomes.

(3) Complementarity of fit, a continuum of support - The study adopts recommendations by contingency researchers concerning a holistic approach to contingencies and towards measurement. Multiple forms of analysis were conducted in order to testify that 'fit' results in higher performance. Such complementarity of fit supports the continuum of fit as advocated by contingency researchers (Drazin \& Van de Ven 1985; Venkatraman \& Prescott 1990). Movement towards higher-level measurement, such as pattern analysis and the development of gestalts, is important to the field of contingency research. The incorporation of pattern analysis in this study, confirms that a firm with a given profile, will be likely to achieve a certain performance level. This form of measurement is considered superior as it goes beyond generalisations of 'why' firms cooperate and instead specifies 'who' cooperates and how that 'cooperation results in performance'. The measurement of fit between strategy and context impacts greatly on research findings, and the generalisability of those findings. 
This research seeks to understand the performance implications of co-marketing and environmental conditions conducive to employ co-marketing strategies [ie result in attenuated performance].

Developing empirical support concerning the performance benefits associated with cooperative marketing and an understanding of the contexts under which performance gains are the greatest when using cooperative marketing strategies are key objectives of this research.

\section{THEORETICAL FOUNDATIONS [MATERIALS]}

The value of strategic responses must be measured, as confirming their value encourages further use of that strategic action. Strategies have varying value under different environmental contexts, and therefore performance variations result (Lee \& Miller 1996; Madsen 1989; Miller 1988; Miller 1991; Miller \& Friesen 1983; Venkatraman 1990; Zajac, Kraatz \& Bresser 2000). Both strategic contingency theory (Chandler 1962; Burns \& Stalker 1961; Katz \& Kahn 1978; Lawrence \& Lorsch 1967) and strategic choice theory (Child 1972) acknowledge strategies are implemented by organisations in response to opportunities or threats from internal and external contingencies in the environment.

The current research context focuses on cooperative marketing arrangements in response to internal and external contingencies and the fitting environmental contexts that support 
the use of this strategy to achieve positive performance implications. Other studies that have focused on performance outcomes as a result of marketing strategy use under various environmental contexts include strategy responses in terms of pricing, product, promotion and distribution (Levitt 1965; Kotler 1984; Day 1986; Nonaka \& Nicosia 1979; Zeithaml, Varadarajan \& Zeithaml 1988). Typically, these studies use a contingency approached by investigating the contextual factors, or environments as a variable directly impacting on performance outcomes.

\section{Alliance Performance Outcomes}

Outcomes measure the impact of fit between strategy and environmental context. The most common outcome measure in contingency research is alliance performance. In a marketing context, the use of marketing strategy or in a management context, the use of managerial strategies, which are coaligned with the environment should provide positive outcomes. Strategic choice theory (Child 1972) notes that management has discretion to influence outcomes, because as decision makers they can choose from a wide range of strategy options. Certainly the use of strategy can have a significant impact on performance. Organisational strategy responses are motivated by performance expectations, which may be economic, efficiency or effectiveness gains (Aldrich 1979; Child 1972).

Outcomes can be assessed by objective or subjective measures. The difficulty faced by researchers in obtaining objective performance measures brings the importance of subjective performance measures to the forefront. Difficulties arise given that there is 
usually a lack of available objective financial data, secondly objective data does not lend itself to measuring strategic objectives and thirdly, there is a need for future oriented outcomes. That is, while financial measurements are popular, as they are comparable across divisions and companies, these measures are more appropriate for long term measures of performance as they reflect a long-term achievement. Furthermore, as researchers argue the need for multidimensional measurement of performance, and incorporation of broader dimensions beyond economic data, the relevance of subjective measure for alliance performance are highlighted

The significance of strategic performance measures is grounded in the importance of providing future oriented dimensions of performance outcomes (Cavusgil 1984; Axinn, Noordewier \& Sinkula 1996). Dess and Robinson (1984) investigated the usefulness of subjective performance measures and while subjective measures are not said to be better than objective measures, their findings indicated that subjective measures, when compared to economic measures of performance were strongly correlated, concerning return on assets and sales. The study attests the accuracy and consistency of subjective measurement. In this research it was cross sectional and many of the alliances were youthful meaning that due to lag effects, economic/financial performance would be difficult to capture (Dalton, Todor, Spendolini, Fielding and Porter, 1980; (Dalton et al. 1980; Habib \& Victor 1991)

Therefore, performance measures for this study are both subjective and at the functional level where firms report on the performance of the venture. The use of firm level or 
venture level measurement (Miller 1987), together with the use of objective or subjective measures must be justified, and be made clear to enable replicable studies and generalisability. This study examines outcomes at the venture level where outcomes are directly linked to the use of cooperative marketing strategies. Miller (1987) and Madsen (1989) both note that there is such a need for individual venture measurement, given that it becomes difficult to assess the impact of strategy on performance when looking at the aggregate firm level.

In this study venture performance outcomes are assessed based on perceived satisfaction and effectiveness which are common measures of strategic alliance performance (Bucklin \& Sengupta 1993; Van de Ven 1976). Key items of the effectiveness scale include "commitment of firms to the alliance" [the extent to which partner carried out responsibilities and commitments; extent your firm carried out responsibilities and commitments], "the degree to which both members find the alliance worthwhile" [extent to which the relationship has been productive], as well as "overall satisfaction" regarding the co-marketing alliance [relationship has been satisfactory] (Van de Ven 1976; Van de Ven \& Ferry 1980; Ruekert \& Walker 1987).

\section{Cooperative Marketing Strategy Implementation}

Cooperative marketing strategy implementation is the strategy response investigated as influencing firm performance under particular situational contexts. Cooperative marketing arrangements are classified as a form of strategic alliance which is based on 
equity (cross ownership) and non-equity participation (verbal or contractual arrangements) at the functional level (Dickinson and Ramaseshan 2004a Dickinson and Ramaseshan 2004b). Cooperative marketing relationships can be carried out using joint or complementary arrangements Joint arrangements include pooling of money, which may facilitate distribution or promotion, or may include the pooling of products which are marketed under a single brand identity. Complementary arrangements may include trading access to distribution channels in each others regions, trading technical information, trading research and development techniques and trading market research or supply inventories. The key benefits of such resource trading, include the reduced duplication of resources and win-win trades (Nielsen 1987; Varadarajan \& Cunningham 1995). Cooperative marketing which is hypothesised to attenuate performance entails cooperation in terms of marketing mix elements (product, promotion, pricing and distribution).

\section{Co-product strategy}

Cooperative product strategies (co-product strategies) occur when firms cooperate across product strategies. Cooperation across actual product characteristics includes joint research and development, joint labelling, branding alliances while cooperating based on augmented product aspects may include offering reciprocal warranty, delivery, credit and after-sales-service.

Cooperative product bundling has received the most attention of all co-product strategies and has previously been linked with performance. Product bundling occurs when a firm 
cooperates with a competitor to combine complementary offerings and is found to generate performance benefits due to cost reductions and price de-escalation from a product development and distribution point of view. Performance benefits are also linked to improved customer satisfaction due to reduced search time and reduced transaction costs for customers when purchasing bundled products (Faquhar, Hulia, Herr \& Yuji 1992). Other positive performance outcomes of cooperative product bundling include better geographic and target market coverage, greater market share and increased market size, as complementary products and services are bundled for better market access (Shamdasani \& Sheth 1995; Varadarajan \& Cunningham 1995). The broadening of product lines through cooperation, can also result in quality and productivity benefits. It can also increase customer satisfaction, and block competition (Crouse 1991; Shamdasani \& Sheth 1995; Spekman \& Sawhney 1990; Terpstra \& Simonin 1992).

Beyond cooperative product bundling, Dieke and Karamustafa (2000), recognise that cooperation across other elements such as branding, packaging, warranties and the like, are all viable and potentially worthwhile. This study operationalises co-product strategy use to include cooperative labelling, cooperative branding, cooperative product development and cooperative packaging as well as product bundling $[1=$ low cooperation, $7=$ high cooperation] (Dieke \& Karamustafa 2000). Based on the above discussion, it is hypothesised that higher levels of co-product strategies will result in increased performance outcomes. 
$H_{1}$ : Firm performance is influenced by co-marketing implementation higher cooperative product strategy use

\section{Cooperative Promotional Strategy}

Promotional strategies comprise more than advertising (the major research focus to date). Firms can cooperate based on advertising, sales promotions, personal selling, public relations and direct marketing activities, each of which would the benefit firms by cost sharing. Cost sharing results in pooling of financial resources so that there is a larger financial outlay at an aggregate level, and therefore increased effectiveness of copromotional campaigns. Cost reductions and better campaigns are likely to develop based on cooperative promotional strategies (Nielsen 1987).

Joint advertising programs have received the most attention from researchers as well as industry due to the expense associated with advertising forcing the need for cooperation. This is particularly evident in an Australian context where the business landscape is dominated by small to medium sized firms, making it difficult to afford promotional expenses (Buttery and Buttery 1998). Certainly, an alliance can become an effective promotional unit and provides firms with an alternative to traditional independent advertising. Shared sponsorship of promotional programs was investigated by Crimmins, $(1989 ; 1988 ; 1984)$ in a vertical context, where co-advertising is between manufacturer and retailer or ingredient-producer, and where raw materials of manufacturers are linked with the end product. The effectiveness of such cooperation is not only based on cost 
improvements, but on brand matching, where being matched with a high quality brand can increase the brand image of their own product (Pisierra, McKinney \& Chawla 1999). Besides advertising, cooperative sales promotions have also been investigated in terms of performance implications. Collective sales effort between firms, according to Varadarajan (1986) enhance image through association with others, as well as gaining expanded retailer interest and a more powerful sale force. Tie-in promotions (joint sales promotions), resulted in greater promotional effectiveness which is attributed to larger financial outlay and cost efficiency, as well as increased trial among new customer groups, and increasing exposure to customers through tie-ins (Varadarajan and Rajaratnam 1986).

Performance stemming from increased promotional effectiveness, as well as gaining an improved reputation due to positive association, are benefits from cooperative promotions (Buttery \& Buttery 1998). Beyond current investigations, which are largely limited to advertising and sales promotion, other cooperative promotional elements include cooperative tradeshow displays, cooperative events management and public relations (Dieke \& Karamustafa 2000). Each are investigated in this study with cooperative promotional strategies operationalised by firm use of cooperative advertising, cooperative sales promotion, cooperative trade show displays and cooperative events management $[1=$ low cooperation $7=$ substantial cooperation $]$. 
The hypotheses formulated in relation to cooperative promotional strategies is that higher levels of cooperative promotion (co-promotion) will result in higher performance outcomes.

$\mathrm{H}_{2}$ Firm performance is influenced by co-marketing implementation higher cooperative promotional strategy use

\section{Cooperative Distribution Strategy}

Distribution, comprising physical and intermediary elements, is another basis for cooperative marketing strategies. Firms can enter into cooperative distribution strategies (co-distribution) with partners, in order to facilitate product or service distribution (intensity and extensiveness geographically) as well as for cost reductions. Sharing distribution channels and access to import and export partners, allows a firm to reduce inventory costs (Nielsen 1987). With increased market access in geographic and demographic markets enhanced performance results.

Piggybacking and cross distribution are two arrangements by which a company distributes the competitors products in an agreed geographical area (Pisano, Russo \& Teece 1988; Terpstra \& Simonin 1992). These cooperative arrangements have been investigated in the past as viable cooperative distribution strategies, however, beyond these elements, cooperative transportation, cooperative warehousing, and cooperative inventory control are other important forms of co-distribution. Furthermore potential codistribution strategies are investigated by Dieke, and Karamustafa (2000), who look at the use of the cooperative internet strategies as a distribution alternative. While they 
investigate this in terms of service providers, that is, tourism operators, this could also be linked to distribution in other various industries. Cooperative distribution in terms of sales offices, in regional areas may also be a beneficial form of cooperative distribution (Dieke \& Karamustafa 2000).

While there is limited investigation of the various distribution elements, it is clear that cooperation across distribution elements is likely to achieve positive performance outcomes. Co-distribution is operationalised by firm use of co-transportation, cowarehousing, and shared intermediaries and joint inventory control [1=low cooperation, $7=$ high cooperation]. Based on this, it is hypothesised that higher levels of cooperative distribution, will result in higher performance outcomes.

$H_{3}$ : Firm performance is influenced by co-marketing implementation of cooperative distribution strategy use

\section{Cooperative pricing}

The need for cooperative pricing strategies is linked to the marketing of bundled products or services, as well as joint branding initiatives. Based on cooperative product/service

offerings, firms may need to manipulate prices to compatible levels. That is, cooperative branding would result in cooperative pricing initiatives, as would product/service bundling among cooperating firms. Pricing packages would perhaps result in reduced pricing initiatives, based on product bundling (Kotler et al. 2001). 
Once a firm cooperates with another by offering compatible products, an agreement between the firms offering that product must be reached. When that pricing initiative is positive for both firms, then positive performance outcomes are likely to result. Again, this positive outcome can result from increased customer satisfaction, as well as better bottom line result for each of the firms. In terms of tourist operators, Dieke, and Karamustafa (2000) note the importance of joint initiatives to keep prices as low as possible. They recommend, minimum and maximum prices in a given region, however government regulation must be taken into account. Joint pricing where several firms' services are priced as a package, may be beneficial, and are hypothesised to impact on performance.

Cooperative pricing is operationalised by use of joint price packages. The hypothesis developed in this study, which relates to cooperative pricing (co-pricing), implies that the existence of co-pricing initiatives or reduction of prices to customers, would increase performance. This may result from higher levels of customer satisfaction, or at an economic level, higher sales levels.

$H_{4}$ : Firm performance is influenced by co-marketing implementation of higher cooperative pricing strategy use

\section{Fitting Environmental Contexts}


Strategic contingency theory is a fitting tool in this study as it goes beyond explanations of 'why' strategy should be used, and instead focuses on fitting contexts (internal and external environments) for a particular strategy, to achieve positive performance outcomes. Strategy is context specific, therefore, understanding the contexts that cooperative marketing strategy is suited to, is important. That is, strategic contingency theory "entails identifying commonly recurring settings and observing how different structures, strategies and behavioural responses fare in each setting" (Zeithaml, Varadarajan \& Zeithaml 1988: 37).

Contingency theory recognises equifinality, where more than one organisational response maximises profit, market position or performance (Zajac, Kraatz \& Bresser 2000). Each organisational response alternative however, is not equally effective under all environmental conditions. Variations in performance are not random, but are based on coalignment between contingency factors and organisational response (Zeithaml, Varadarajan \& Zeithaml 1988). Periods of disequilibrium and an organisations' capacity to understand its operating environment and to make appropriate changes, determine competitive strength (Nadler \& Tushman 1999). Situational relevance is vital, as strategies have varying utilities under different settings, and therefore performance variations result (figure 2.2) (Lee \& Miller 1996; Madsen 1989; Miller 1988; Miller 1991; Miller \& Friesen 1983; Venkatraman 1990; Zajac, Kraatz \& Bresser 2000). Traditional studies which have all supported the link between environment and strategy include Hofer (1975), Utterback (1979), Rumelt (1974), Cooper and Schendel (1976), Glueck (1976) and Pain and Anderson (1977). The results are noteworthy, however are 
tentative due to the partist approach towards contingencies and inadequate measurement of fit - hence the need to investigate multiple contingencies. The idea of a "new contingency approach" is based on criticisms of past contingency research and new analytical tools available to researchers. A "new contingency approach" is a holistic investigation of the environment where several contingencies are incorporated into a single study. This provides a more realistic impression of organisational reality, as firms must base their responses on the entire environment, not just a single element of the environment (Miller 1981).

While this study has emphasised the links between cooperative marketing strategy and performance outcomes, such outcomes are hypothesised to be attenuated when strategies are implemented under specific environmental conditions. That is, the appropriateness of cooperative marketing strategy implementation must be in fitting environmental contexts. These environmental contexts are internal (firm and management characteristics) and external (industry and regional) factors.

The importance of "fit" is highlighted in contingency theory research which links contingencies [firm, management, industry and regional factors] and organisational response [strategy decisions]. Firms need to achieve 'consistency', 'congruency', 'coaliagnment' or 'match' (Venkatraman \& Prescott 1990) to achieve positive performance from strategies. That is, fit between the contingency and organisational response is requisite for positive performance. 
Firm characteristics comprise the internal features of the firm. Those used in this study that have received strong attention are firm size (Cavusgil and Zou 1994; Varadarajan and Cunningham 1995), resource competence (Pfeffer and Salancik 1978; Ruekert and Walker 1987; Cravens, Shipp et al. 1993; Cavusgil and Zou 1994; Varadarajan and Cunningham 1995; Zajac, Kraatz et al. 2000), firm experience, (Varadarajan and Cunningham 1995) and partner match (Achrol, Scheer et al. 1990; Spekman and Sawhney 1990; Bucklin and Sengupta 1993).

Managerial characteristics are important as there is no way to separate managers' personal values when making strategic choices. Important dimensions of managerial characteristics used in this study and past research are management attitudes (Cravens, Shipp et al. 1993; Jaworski and Kohli 1993; Priem 1994; Varadarajan and Cunningham 1995), managerial experience (Song 1982; Chaganti and Sambharya 1987; Eisenhardt and Schoonhoven 1990; Beamish, Craig et al. 1993; Cravens, Shipp et al. 1993; Cavusgil and Zou 1994; Evangelista 1994) and managerial perceptions in relation to risk associated with cooperation, the benefits of cooperation, the profitability of cooperation and skill level regarding cooperation (Evangelista, 1994; Wilkinson and Barrett 1987).

Besides internal determinants, external contingencies also impact on a firms' strategic response and how effective their strategy decisions will be. The dimensions of the industry characteristics construct are largely based around competitiveness and technology intensiveness (Jaworski and Kohli 1993) entry requirements, competitive intensity (Frazier 1983) and environmental capacity (Aldrich 1979; Dess and Beard 
1984) Regional characteristics can prove a hinderance to firm responses, making responses difficult and even unfeasible and for cooperation to be fitting my have to include proximity and infrastructure links (Hill and Shaw 1995; Akoorie 1998; Ingley 1999)

The last hypothesis of this study relates to this relationship between strategy implementation and performance being moderated by 'fit'. That is, under certain environmental conditions (external and internal influences) performance outcomes vary when implementing cooperative marketing strategies.

H6 Firm performance outcomes are contingent on fit between contingencies and cooperative marketing strategy response

\section{Take in Figure 1 about here}

\section{METHOD}

As a cross sectional study, firm responses were measured regarding a specific cooperative marketing venture for the duration of its existence. The data collection is monadic, with the unit of analysis being the business unit. Measurement is at the individual venture level as it becomes difficult to assess the impact of strategy on performance when looking at the aggregate firm level Madsen (1989). 
The population is all businesses engaged in cooperative marketing arrangements in a cross section of industries Data was collected from these nominated industries via a selfadministered mail survey consisting of scaled response questions. In order to address non-response bias, this study used a two-step design. Firstly, a copy of the questionnaire and covering letter were sent to each of the sample respondents. Secondly, after a fourweek lapse in response time, a second covering letter and questionnaire were sent to each of the non-respondents. Due to anonymity, unless respondents chose to identify themselves, then all remaining respondents were re-contacted and told to disregard the correspondence if they had already submitted an anonymous response. In order to further increase the response rate, each of the covering letters were personally addressed to the "Manager" or "Marketing Manager" and a reply-paid envelope was also issued. Lastly, a copy of summary findings was another incentive offered to ensure a high response rate.

In total, 409 completed questionnaires were returned completed. Two sample frames were used. The first sample from was a commercial business listing (Dunn and Bradstreet) and from the initial mail-out (1561), 301 responses were received. Triangulation refers to the use of more than one sample frame, and is advocated by Newman (1994), as looking at something from different angles or viewpoints allows for more realistic representation. Triangulation can however, also refer to both data collection and types of measures (Newman 1994). It was appropriate to pool the two sample given that they were comparable across key aspects such as firm size, location, industry and experience (supported with there be no statistically significant variation across these key characteristics).This resulted in a 19\% response rate. From the second 
sample frame (Ministry of Fair Trading cooperative listings), of the 445 listed, 108 respondents replied. This is a $24 \%$ response rate. In total, 301 responses from sample frame one and 108 responses from sample frame two resulted in a total of 409 completed questionnaires being received.

From the total 409 responses, 199 firms were used to test hypotheses developed in this study as they had currently or had been recently involved in a cooperative arrangement. The 210 respondents that had not been involved in any cooperative marketing arrangement were not used to answer research objectives in this study. The scales included demographic, environmental, cooperative marketing and performance indicators (Appendix 1).

\section{RESULTS}

In total, 199 firms were "currently" or had "recently" been involved in a cooperative marketing arrangement and were used to test the hypotheses outlined in this paper. The majority of respondents were from agriculture (including aquaculture and horticulture) (22.4\%), with other major respondent groups being manufacturing (20.4\%), retailing $(15.2 \%)$ and viticulture (10.8\%). These response rates are comparable with sample frame populations and are consistent with the proportions mailed to each industry sector.

Similarly, as with past findings, respondents were mostly small firms when classified according to the Australian Bureau of Statistics' (ABS) firm size categories. In total, 55\% 
of respondents had fewer than 20 employees, with large firms accounting for only $9 \%$ of respondents. These findings are consistent with other research conducted in Australia, such as that by Evangelista (1994) where $72 \%$ of respondents had fewer than 100 employees, as well as research by the ABS, where small business accounts for $97 \%$ of all private sector businesses in Australia (McLennan 1998).

Initial scale measurement comprised 12 items that operationalised cooperative marketing. Overall, cooperative marketing strategies had "moderate use" by firms. Of all the forms of cooperative marketing, cooperative product development (mean 4.58), together with cooperative product bundling (mean 4.51) and cooperative service bundling (4.51) were the most popular forms of cooperation. The least popular type of cooperation occurs in relation to cooperative events management (mean 3.50).

Prior to testing at the multivariate level, internal consistency was tested by using Cronbach Alpha (Coakes and Steed 1997; Norusis 1997). The alpha level used in this study is 0.6 . In order to further produce reliable factor analysis, multicollinearity between statements was dealt with by deleting those statements that had a squared multiple correlation of above 0.70 and in terms of testing for univariate normality, the Kolmogorov-Smirnov test was the formal statistic used with all constructs having a significance level greater than 0.05 which indicated normality (Norusis 1997).

Each of the seven constructs, which comprise "firm characteristics", "management characteristics", "industry characteristics", "regional characteristics", "cooperative 
marketing strategy", and "performance outcomes", used multiple-item measures (Appendix I). Factor analysis (Appendix II was used in this study for both data reduction, and substantive interpretation. For each of the constructs, the key assumptions of principal axis factor analysis are met, and sample size is sufficient. Normality was evident, and outliers were removed. Those factors with eigenvalues of greater than 0.7 (Khattree 1999) are included as factors and used in multiple regression and discriminant analysis.

Analysis begins at the lower end of the analytical spectrum with Independent t-tests, conducted to discern whether there are significant differences between cooperative marketing strategy use and perceived alliance performance.

New factors were input into independent t-test analysis aimed at comparing the mean levels of "co-distribution", "co-promotion", "co-product" and "co-branding" strategy implementation among low and high performance firms. Results from independent t-test support hypotheses that indicate there is a significant relationship between the comarketing strategy implementation and perceived alliance performance. That is, firms who had high levels of co-distribution $(\mathrm{p}=.039)$, co-promotion $(\mathrm{p}=.001)$, co-product $(\mathrm{p}=.001)$ and co-branding $(\mathrm{p}=.010)$ strategy implementation, had significantly higher levels of performance at the $95 \%$ confidence interval. Conversely, lower levels of their implementation were related to lower levels of perceived alliance performance (Table 1).

\section{'Take in Table I about here'}


Beyond confirming the link between co-marketing and performance in general, contexts that are conducive to use of co-marketing are investigated. Cluster analysis and discriminant analysis was carried out to identify cooperative alliance performance clusters and the "profile" of firms within the designated performance clusters. Based on dendogram output, three distinct performance clusters emerged. Further to graphical interpretation, the agglomeration schedule coefficients were studied, and the distance between successive clusters again reinforced a three-cluster. Those firms that had high cooperative marketing alliance performance are considered to have the 'ideal profile' that is they have achieved fit, therefore understanding such fit can provide future models for achieving high performance.

The cluster with the highest perceived performance was "Cluster Two". This cluster also had the highest level of cooperative marketing strategy implementation -continuing the systematic evidence that co-marketing does impact on performance. Clearly, high performance is associated with high levels of cooperative marketing, however, further to this, values across other factors are observed.

Beyond the basic comparisons of mean ratings for each of the general internal and external contingency constructs, discriminant analysis allows the determination of the specific dimensions significantly able to distinguish cluster membership. Two canonical functions distinguished between cluster membership and were validated (using maximum chance criterion and proportional chance criterion) prior to discriminant analysis. 
Based on the rank of independent variables in terms of their relative discriminatory power, the significant variables that differentiated cluster membership were industry and regional factors (Table II and III). That is, these high performance firms had the highest use of co-marketing arrangements however were confronted by the highest entry requirements (capital requirements), the highest levels of competitive intensity and the highest levels of environmental capacity (potential for product or market growth). Good quality infrastructure (telecommunications and road) were also distinct for this group. That is, high performance firms achieved such levels of perceived performance when having high levels of co-marketing under these industry and regional conditions.

\section{'Take in Table II and Table III about here'}

\section{DISCUSSION - alter to perceived performance throughout}

Data analysis provides evidence concerning perceived performance as a result of cooperative marketing strategy use. Overall, most firms had moderate use of cooperative marketing strategies. Of all the forms of cooperative marketing, cooperative product development together with cooperative product bundling and cooperative service bundling, show the highest levels of cooperation. The lowest level of cooperation occurs in relation to cooperative events management. 
Factor analysis was conducted to reduce the number of dimensions used to operationalise the research model. As a result, the 12 forms of co-marketing were reduced to four key dimensions that include "co-product", "co-promotion", "co-distribution" and "cobranding”. Each individual dimension as well as the overall construct of co-marketing was confirmed to result in positive performance outcomes. This is consistent with past findings. That is, higher levels of cooperative product strategies (Spekman \& Sawhney 1990), promotional cooperation (Nielsen 1987; Buttery \& Buttery 1998; Varadarajan 1986), as well as cooperative distribution (Dieke \& Karamustafa 2000; Nielsen 1987), were all linked to increased performance.

The impact of co-marketing on performance was assessed along a continuum of measurement (independent t-tests and discriminant analysis). The results consistently indicate that the higher the incidence of cooperative marketing strategy implementation, the higher performance outcomes. Cooperative marketing strategy has the highest benefit (positive performance outcomes) when used in fitting contexts. The results indicate that cooperative marketing has a significant impact on performance. Further support relating to the link between cooperative marketing and performance was based on cluster analysis. Rather than just stating that cooperative marketing is linked to performance, it is beneficial to explain the environmental contexts under which this performance is the highest.

Based on cluster analysis, the highest performing cluster was "Cluster Two". This cluster was distinct in terms of its high levels of co-marketing, as well as industry and regional 
characteristics. Performance was positive as a result of co-marketing where there were higher levels of co-marketing, good quality infrastructure (roads and telecommunications), and under industry conditions where there was high entry requirements (firms needing assistance in carrying the burden of entry demands (Porter 1985; Dieke \& Karamustafa 2000), high competitive intensity (Varadarajan 1986; YasaiArdekani \& Haug 1997) and high levels of environmental capacity (room for growth in a product category or market segment) (Dess \& Robinson Jr 1984; McGinnis \& Kohn 1993).

Overall, there is a confirmed link between co-marketing strategy implementation and performance outcomes across several measures. Additionally, in terms of generating positive performance outcomes, an insight into the fitting conditions for co-marketing strategy implementation is detailed. At each level, support for the performance implications of co-marketing strategy implementation is provided.

\section{Managerial Implications and Future Research Directions}

In both international and domestic contexts, the market challenges faced by firms highlight the relevance of cooperation as a strategic alternative to competition. It is important for management in any company to be aware of the benefits of cooperation in terms of the related performance implications. Certainly, the usefulness of cooperative marketing arrangements hinges on potential performance outcomes resulting from such strategy arrangements. Given that this research has provided empirical support relating to the performance benefits of cooperative marketing, practitioners can benefit from the 
identification of such performance linkages as well as a comprehension of the functional cooperative marketing strategies appropriate under certain environmental conditions.

Cooperative marketing arrangements provide increased performance in given contexts. That is, there are positive performance variations resulting from the implementation of cooperative marketing under the right conditions. This finding is consistent throughout several levels of measurement and has significant implications for resource deployment, and the use of co-marketing by firms who exhibit similar characteristics to those described. Those firms that are operating under similar conditions to "Cluster 2" type firms should take actions to stimulate partnerships.

That is, firms that are facing competitive environments or environments where there is great potential for product or market growth need to recognise strategy solutions for achieving positive performance. They can work to make sure that internal contingencies over which they have a degree of control are well matched to support co-marketing strategy implementation. Furthermore, firms facing high competition or entry requirements, should not despair, but should instead embrace the array of cooperative marketing opportunities that exist is many diverse forms.

Firms facing the described contingencies should know that co-product, co-promotion, codistribution and co-branding strategies can be used as a performance enhancing tool. They can reduce the likelihood of business failure and attenuate performance through cooperative marketing. An understanding of the ideal profile of high performance 
cooperators can provide managers exhibiting such a profile with a level of confidence in their strategy decisions so that they are proactive in seeking out cooperative marketing opportunities. As a result of findings in this study, firms can gain increased confidence in their application of cooperative marketing strategies to business environments.

\section{Future Research Directions}

There are several useful directions for future research that stem from limitations associated with this study. In terms of an agenda for ongoing research, research that can broaden the findings from this study and investigate cooperative marketing in varying contexts is required. Additionally research that tests the stability of factors over time and across samples in different regions and different industry sectors would be useful. Researchers can use the new factors that measure the cooperative marketing construct to confirm scale validity and stability, while additional testing of the factors across nationalities would provide support relating to their generalisability. Lastly, while this study does incorporate cooperation across service elements, it would also be interesting to develop a comparison of cooperative marketing antecedents in the goods and service sector and also, for profit and not for profit organisations. 


\begin{tabular}{|l|c|}
\hline \multicolumn{1}{|c|}{ Hypotheses } & $\begin{array}{c}\text { Accepted } \\
\text { /Rejected }\end{array}$ \\
\hline $\begin{array}{l}\text { H1: Firm performance is influenced by co-marketing implementation higher } \\
\text { cooperative product strategy use }\end{array}$ & Accepted \\
\hline $\begin{array}{l}\text { Firm performance is influenced by co-marketing implementation higher cooperative } \\
\text { promotion strategy use }\end{array}$ & Accepted \\
\hline $\begin{array}{l}\text { H3: Firm performance is influenced by co-marketing implementation higher } \\
\text { distribution strategy use }\end{array}$ & Accepted \\
\hline $\begin{array}{l}\text { H4: Firm performance is influenced by co-marketing implementation higher } \\
\text { cooperative pricing strategy use }\end{array}$ & Accepted \\
\hline $\begin{array}{l}\text { H5: Firm performance outcomes are contingent on fit between contingencies and } \\
\text { cooperative marketing strategy response }\end{array}$ & Accepted \\
\hline
\end{tabular}




\section{REFERENCES}

Akoorie, M. E. M. 1998, 'Encouraging Small Firm Internationalisation: A Tripartite examination of recent policy prescriptions in Denmark, Australia and New Zealand', University of Melbourne.

Aldrich, H. E. 1979, Organisations and Environments, Prentice Hall Inc, Englewood Cliffs, NJ.

Anderson, J. C. \& Narus, J. A. 1991, 'Partnering as a Focused Market Strategy', California Management Review, vol. Spring, pp. 95-113.

Andrews, K. R. 1971, The Concept of Corporate Strategy, Dow Jones-Irwin, Homewood, IL.

Arndt, J. 1979, 'Towards a Concept of Domesticated Markets', Journal of Marketing, vol. 43, no. Fall, pp. 69-75.

Bantel, K. A. \& Jackson, S. E. 1989, 'Top Management and Innovations in Banking: Does the composition of the top team make a difference?', Strategic Management Journal, vol. 10, pp. 107-124.

Beamish, P. W., Craig, R. \& McLellan, L. 1993, 'The Performance Characteristics of Canadian versus UK Exporters in Small and Medium Sized Firms', Management Intenational Review, vol. 33, no. 2, pp. 121-137.

Bodur, M. 1994, 'Foreign Market Indicators, Structural Resources and Marketing Strategies as Determinants of Export Performance', Advances in International Marketing, vol. 6, pp. 183-205.

Bucklin, L. P. \& Sengupta, S. 1993, 'Organizing Successful Co-marketing Alliances', Journal of Marketing, vol. 57, no. 2, pp. 32-46.

Buttery \& Buttery 1998, 'The Impact of Networking on Marketing', Journal of the Australian and New Zealand Academy of Management, vol. 4, no. 2, pp. 27-36.

Caruana, A., Ewing, M. \& Ramaseshan, B. 1999, 'The Effects of Environmental Challenges and Centralisation on the Entrepreneurial Orientation and Performance of Public Sector Entities', In Working Paper Series Number 9910, Curtin University of Technology, Curtin Business School, pp. 1-13.

Cavusgil, S. T. \& Kirpalani, V. H. 1993, 'Introducing Products Into Export Markets: Success factors', Journal of Businesss Research, vol. 27, pp. 1-15. 
Cavusgil, S. T. \& Zou, S. 1994, 'Marketing Strategy-Performance Relationship: An investigation of the empirical link in export market ventures', Journal of Marketing, vol. 58, pp. 1-21.

Chaganti, R. \& Sambharya, R. 1987, 'Strategic Orientation and Characteristics of Upper Management', Strategic Management Journal, vol. 8, pp. 393-401.

Covin, J. G. \& Slevin, D. P. 1991, 'A Conceptual Model of Entrepreneurship as Firm Behaviour', Entrepreneurship Theory and Practice, vol. Fall, pp. 7-25.

Cravens, D. W., Shipp, S. H. \& Cravens, K. S. 1993, 'Analysis of Cooperative Interorganizational Relationships, Strategic Alliance Formation, and Strategic Alliance Effectiveness', Journal of Strategic Marketing, vol. 1, pp. 55-70.

Crouse, H. J. 1991, 'The Power or Partnerships', The Journal of Business Strategy, vol. November/December, pp. 4-8.

Datta, D. K. 1991, 'Organizational Fit and Acquisition Performance: Effects of postacquisition integration', Strategic Management Journal, vol. 12, pp. 281-297.

Dess, G. G. \& Beard, D. W. 1984, 'Dimensions of Organizational Task Environments', Administrative Science Quarterly, vol. 29, no. March, pp. 52-73.

Dess, G. G. \& Robinson Jr, R. B. 1984, 'Measuring Organizational Performance in the Absence of Objective Measures: The case of the privately-held firm and conglomerate business unit', Strategic Management Journal, vol. 5, pp. 265-273.

Dickinson, S, J., Ramaseshan, B (2004a) 'An Investigation of the Antecedents to Cooperative Marketing Strategy Implementation' Journal of Strategic Marketing, Vol 12, No 2, p71

Dickinson, S.J., Ramaseshan, B (2004b) 'The Patterns of Cooperative Marketing in Australia', Small Enterprise Research -The Journal of SEAANZ, vol12 no2, p47

Dieke, P. U. C. \& Karamustafa, K. 2000, 'Cooperative Marketing in the Accommodation Subsector: Southeastern Meditteranean perspectives', Thunderbird International Business Review, vol. 42, no. 4, pp. 467-494.

Drazin, R. \& Van de Ven, A. H. 1985, 'Alternative Forms of Fit in Contingency Theory', Administrative Science Quarterly, vol. 30, pp. 514-539.

Eisenhardt, K. M. \& Schoonhoven, C. B. 1990, 'Organizational Growth: Linking founding team, strategy, environment and growth among US semiconducture ventures, 1978-1988', Administrative Science Quarterly, vol. 35, pp. 504-529. 
Evangelista, F. U. 1994, 'Export Performance and its Determinants: Some empirical evidence from Australian manufacturing firms', Advances in International Marketing, vol. 6, pp. 207-229.

Frazier, G. L. 1983, 'Interorganizational Exchange Behaviour in Marketing Channels: A broadened perspective', Journal of Marketing, vol. 47, no. Fall, pp. 68-78.

Grimm, C. M. \& Smith, K. G. 1991, 'Management and Organizational Change: A note on the railroad industry', Strategic Management Journal, vol. 12, pp. 557-562.

Hair, J. G., Anderson, R. E. \& Tatham, R. L. Black, W.C 1998, Multivariate Data Analysis Fifth edn, Prentice Hall, New Jersey.

Hair, J. G., Anderson, R. E. \& Tatham, R. L. 1990, Multivariate Data Analysis with Readings, Second edn, Macmillan, New York.

Hall, R. H. 1987, Organisations: Structures, processes and outcomes, Fourth edn, Prentice Hall, Sydney.

Hambrick, D. C. 1983, 'High Profit Strategies in Mature Capital Goods Industries: A Contingency Approach', Academy of Management Journal, vol. 26, pp. 687-707.

Hegert, M. \& Morris, D. 1988, 'Trends in International Collaborative Agreements', in Cooperative Strategies in International Business, Lexington Books, Lexington, MA.

Hill, T. \& Shaw, R. N. 1995, 'Co-marketing Tourism Internationally: Bases for strategic alliances', Journal of Travel Research, vol. 41, no. 1, pp. 25-32.

Ingley, C. 1999, 'Small Firms and Business Networks', in 12th Annual SEAANZ

Conference, eds. Jago, D. L. K. \& Breen, J., Victoria University, pp. 159-178.

Jaworski, B. J. \& Kohli, A. K. 1993, 'Market Orientation: Antecedents and consequences', Journal of Marketing, vol. 57, no. 3, pp. 53-70.

Katz, D. \& Kahn, R. L. 1966, The Social Psychology of Organizations, John Wiley and Sons, New York.

Lee, J. \& Miller, D. 1996, 'Strategy, Environment and Performance in Two Technological Contexts: Contingency theory in Korea', Organization Studies, vol. 17, no. 5, pp. 729-750.

Luo, Y. 1999, 'Environment-Strategy-Performance Relations in Small Businesses in China: A case of township and village enterprises in Southern China', Journal of Small Business Management, vol. 37, no. 1, pp. 37-52. 
Madsen, T. K. 1989, 'Successful Export Marketing Management: Some empirical evidence', International Marketing Review, vol. 6, no. 4, pp. 41-57.

Mak, Y. T. 1989, 'Contingency Fit, Internal Consistency and Financial Performance', Journal of Business Finance and Accounting, vol. 16, no. 2, pp. 273-.

March, J. G. \& Simon, H. A. 1958, Organizations, Wiley, New York.

McGinnis, M. A. \& Kohn, J. W. 1993, 'Logistics Strategy, Organizational Environment, and Time Competitiveness', Journal of Business Logistics, vol. 14, no. 2, pp. 1-13.

McGuinness, N. W. \& Little, B. 1981, 'The Influence of Product Characteristics on the Export Performance of New Products', Journal of Marketing, vol. 45, pp. 110-122.

McLennan, W. 1998, Small Business in Australia 1997: Catalogue 1321.0, Australian Bureau of Statistics, Canberra.

Miller, D. 1981, 'Toward a New Contingency Perspective: The search for orgnizational gestalts', Journal of Management, vol. 18, pp. 1-26.

Miller, D. 1987, 'The Structural and Environmental Correlates of Business Strategy', Strategic Management Journal, vol. 8, no. 1, pp. 55-77.

Miller, D. 1988, 'Relating Porter's Business Strategies to Environment and Structure: Analysis and performance implications', Academy of Management Review, vol. 31, no. 2, pp. 280-308.

Miller, D. 1991, 'Stale in the Saddle: CEO tenure and the match between organization and environment', Management Science, vol. 37, no. 1, pp. 34-52.

Miller, D. \& Friesen, P. H. 1983, 'Strategy-Making and Environment: The third link', Strategic Management Journal, vol. 4, no. 3, pp. 221-235.

Morgan, R. M. \& Hunt, S. D. 1994, 'The Commitment-Trust Theory of Relationship Marketing', Journal of Marketing, vol. 58, pp. 20-38.

Naman, J. L. \& Slevin, D. P. 1993, 'Entrepreneurship and the Concept of Fit: A model and empirical tests', Strategic Management Journal, vol. 14, no. 2, pp. 137-154.

Nielsen, R. P. 1987, 'Cooperative Strategy in Marketing', Business Horizons, vol. 30, no. 4, pp. 61-68.

Ozsomer, A. \& Prussia, G. E. 2000, 'Competing Perspectives in International Marketing Strategy: Contingency and process models', Journal of International Marketing, vol. 8, no. 1 , pp. $27-50$. 
Parthasarthy, R. \& Prakash, S. S. 1992, 'The Impact of Flexible Automation on Business Strategy and Organizational Structure', The Academy of Management Review, vol. 17, no. 1, pp. 86-104.

Pfeffer, J. \& Salancik, G. R. 1978, The External Control of Organizations: A resource dependence perspective, Harper and Row, New York.

Pisano, G. P., Russo, M. V. \& Teece, D. J. (eds.) 1988, Joint Ventures and Collaborative Arrangements in the Telecommunications Equipment Industry, Ballinger Publishing Company, Cambridge.

Porter, M. E. 1985, Competitive Advantage: Creating and sustaining superior performance, Free Press, New York.

Priem, R. L. 1994, 'Executive Judgement, Organizational Congruence, and Firm Performance', Organization Science, vol. 5, no. 3, pp. 421-438.

Ruekert, R. W. \& Walker, O. C. 1987, 'Marketing's Interaction with Other Functional Units: A conceptual framework and empirical evidence', Journal of Marketing, vol. 51, pp. 1-19.

Schoonhoven, C. B. 1981, 'Problems with Contingency Theory: Testing assumptions hidden within the language of contingency "theory"', Administrative Science Quarterly, vol. 26, no. 349-377.

Shamdasani, P. N. \& Sheth, J. N. 1995, 'An Experimental Approach to Investigating Satisfaction and Continuity in Marketing Alliances', European Journal of Marketing, vol. 29, no. 4, pp. 6-23.

Snow, C. C. \& Hrebiniak, L. G. 1980, 'Strategy, Distinctive Competece and Organizational Performance', Administrative Science Quarterly, vol. 25, pp. 317-336.

Snow, C. C. \& Miles, R. E. 1983, 'The Role of Strategy in the Development of a General Theory of Organizations', Advances in Strategic Management, vol. 2, pp. 2231-259.

Song, J. H. 1982, 'Diversification Strategies and the Experience of Top Executives of Large Firms', Strategic Management Journal, vol. 3, pp. 377-380.

Spekman, R. E. \& Sawhney, K. 1990, Towards a Conceptual Understanding of The Antecedents of Strategic Alliances, Marketing Science Institute, Cambridge, 90-114.

Styles, C. \& Ambler, T. 1997, First Steps to Export Success: A project by the Pan'agra Research Programme of London Business School.

Terpstra, V. \& Simonin, B. L. 1992, 'Strategic Alliances in the Triad: An exploratory study', Journal of International Marketing, vol. 1, no. 1, pp. 4-25. 
Thompson, J. D. 1967, Organizations in Action, McGraw Hill, New York.

Van de Ven, A. H. 1976, 'On the Nature, Formation and Maintenance of Relations Among Organizations', Academy of Management Review, vol. 1, no. 10, pp. 24-36.

Van de Ven, A. H. \& Drazin, R. (eds.) 1985, The Concept of Fit in Contingency Theory, JAI Press, Greenwich, Conn.

Van de Ven, A. H. \& Ferry, D. L. 1980, Measuring and Asessing Organizations, Wiley and Sons, New York.

Varadarajan, P. R. 1986, 'Horizontal Cooperative Sales Promotion: A framework for classification and additional perspectives', Journal of Marketing, vol. 50, pp. 61-73.

Varadarajan, P. R. \& Cunningham, M. H. 1995, 'Strategic Alliances: A synthesis of conceptual foundations', Journal of the Academy of Marketing Science, vol. 23, no. 4, pp. 282-296.

Varadarajan, P. R. \& Rajaratnam, D. 1986, 'Symbiotic Marketing Revisited', Journal of Marketing, vol. 50, pp. 7-17.

Venkatraman, N. 1989, 'The Concept of Fit in Strategy Research: Toward verbal and statistical correspondence', Academy of Management Review, vol. 14, no. 3, pp. 423-444.

Venkatraman, N. 1990, 'Performance Implications of Strategtic Coalignment: A methodolgical perspective', Journal of Management Studies, vol. 27, no. 1, pp. 19-41.

Venkatraman, N. \& Camillus, J. C. 1984, 'Exploring the Concept of 'Fit' in Strategic Management', Academy of Management Journal, vol. 9, no. 3, pp. 513-525.

Venkatraman, N. \& Prescott, J. E. 1990, 'Environment-Strategy Coalignment: An empirical test of its Performance Implications', Strategic Management Journal, vol. 11, no. 1, pp. 1-23.

Wilkinson, I. F. \& Barrett, N. J. 1987, In Search of Excellence in Exporting: an analysis of the 1986 Australian Export Award winners, Australian Trade Commission.

Yasai-Ardekani, M. \& Haug, R. S. 1997, 'Contextual Determinants of Strategic Planning Processes', The Journal of Management Studies, vol. 34, no. 5, pp. 729-767.

Zajac, E. J., Kraatz, M. S. \& Bresser, R. K. F. 2000, 'Modelling the Dynamics of Strategic Fit: A normative approach to strategic change', Strategic Management Journal, vol. 21, no. 4, pp. 429-453. 
Zeithaml, V. A., Varadarajan, P. \& Zeithaml, C. P. 1988, 'The Contingency Approach: Its foundations and relevance to theory building and research in marketing', European Journal of Marketing, vol. 22, no. 7, pp. 37-64. 
APPENDIX I Operationalised Construct Measurement Construct Measurement

\begin{tabular}{|c|c|c|c|}
\hline \multicolumn{4}{|c|}{ Construct Measurement } \\
\hline Construct & Indicator & Measurement & Source \\
\hline \multicolumn{4}{|c|}{ PERFORMANCE } \\
\hline Venture Business Performance & $\begin{array}{l}\text { Partner carried out responsibilities \& } \\
\text { commitments } \\
\text { Your firm carried our responsibilities \& } \\
\text { commitments } \\
\text { Relationship been productive } \\
\text { Relationship been satisfactory }\end{array}$ & 7 - point scale & $\begin{array}{l}\text { Van de Van } \\
\& \text { Ferry } \\
(1980) ; \\
\text { Ruekert \& } \\
\text { Walker } \\
(1987)\end{array}$ \\
\hline \multicolumn{4}{|c|}{ FIRM CHARACTERISTICS } \\
\hline Structure & $\begin{array}{l}\text { To arrangement is } \\
\text { Informal/non-binding } \\
\text { A formal contract } \\
\text { Another legal entity created } \\
\text { A brand name developed }\end{array}$ & Categorical & Original \\
\hline Structure/Formalisation & $\begin{array}{l}\text { To what extent have the terms of the } \\
\text { relationship between you and this other } \\
\text { unit: } \\
\text { Been explicitly verbalised or discussed? } \\
\text { Been written down in detail? } \\
\text { Have standard operating procedures } \\
\text { been established? } \\
\text { Are formal communication channels } \\
\text { followed? }\end{array}$ & $\begin{array}{l}\text { 7-point scale } \\
\text { 1=To no extent } \\
\text { 4=Considerable extent } \\
\text { 7=To great extent }\end{array}$ & $\begin{array}{l}\text { (Van de } \\
\text { Ven \& } \\
\text { Ferry } \\
1980 ; \\
\text { Ruekert \& } \\
\text { Walker } \\
\text { 1987) }\end{array}$ \\
\hline Firm Size & $\begin{array}{l}\text { Number of full time equivalent } \\
\text { employees }\end{array}$ & Ratio & Original \\
\hline Firm Alliance Experience & $\begin{array}{l}\text { Number of years involved in the } \\
\text { cooperative venture } \\
\text { Involvement in a single or multiple } \\
\text { arrangements }\end{array}$ & $\begin{array}{l}\text { Ratio } \\
1=\text { single } \\
2=\text { simulataneous } \\
\text { multiple }\end{array}$ & $\begin{array}{l}\text { (Cavusgil } \\
\& \\
\text { Kirpalani } \\
1993 \text { ) }\end{array}$ \\
\hline Firm Competence & $\begin{array}{l}\text { Product, pricing, promotion, physical } \\
\text { distribution, channel distribution, } \\
\text { branding competence }\end{array}$ & $\begin{array}{l}7 \text { - point scale } \\
\text { 1=Low competence } \\
\text { 4=Moderate competence } \\
\text { 7=High competence }\end{array}$ & $\begin{array}{l}\text { Also (Snow } \\
\& \\
\text { Hrebiniak } \\
1980 \text { ) } \\
\text { From } \\
\text { (Evangelis } \\
\text { ta 1994) }\end{array}$ \\
\hline Firm Commitment & $\begin{array}{l}\text { Relationship with partners: } \\
\text { Something we are committed to } \\
\text { Is very important to us } \\
\text { Is very much like a family } \\
\text { Is something my firm really cares about } \\
\text { Is of very little significance to us } \\
\text { Is something we intend to maintain } \\
\text { indefinitely } \\
\text { Deserves our maximum effort to }\end{array}$ & $\begin{array}{l}7 \text { - point scale } \\
1=\text { strongly agree } \\
4=\text { agree } \\
7=\text { strongly disagree }\end{array}$ & $\begin{array}{l}\text { (Morgan } \\
\text { \& Hunt } \\
1994 \text { ) }\end{array}$ \\
\hline
\end{tabular}




\begin{tabular}{|c|c|c|c|}
\hline & maintain & & \\
\hline Behavioural Commitment & $\begin{array}{l}\text { Company sets aside funds } \\
\text { Travel frequently } \\
\text { High priority activity } \\
\text { Company responds rather than pursues } \\
\text { opportunities }\end{array}$ & $\begin{array}{l}\text { 7-point scale } \\
1=\text { strongly disagree } \\
4=\text { agree } \\
7=\text { strongly agree }\end{array}$ & $\begin{array}{l}\text { (Evangelis } \\
\text { ta 1994) }\end{array}$ \\
\hline $\begin{array}{l}\text { Partner Match/Domain } \\
\text { Similarity }\end{array}$ & $\begin{array}{l}\text { The extent to which the other firm } \\
\text { Does the same kind of work } \\
\text { Has the same clients or customers } \\
\text { Has similar operating goals } \\
\text { Employees have similar } \\
\text { professional/trade skills } \\
\text { Partner Match/History: } \\
\text { Prior to the partnership } \\
\text { Our firm had business relations with } \\
\text { partner firm } \\
\text { Our firm did very little business with } \\
\text { partner firm (reversed) } \\
\text { The history of relations between firms is } \\
\text { stable and enduring }\end{array}$ & $\begin{array}{l}\text { 7-point scale } \\
\text { 1=No Extent } \\
\text { 4=Considerble extent } \\
\text { 7= Great extent } \\
\text { 7-point scale } \\
\text { 1=No Extent } \\
\text { 4=Considerble extent } \\
\text { 7=Great extent }\end{array}$ & $\begin{array}{l}\text { (Van de } \\
\text { Ven \& } \\
\text { Ferry } \\
\text { 1980; } \\
\text { Ruekert \& } \\
\text { Walker } \\
\text { 1987) } \\
\\
\text { (Van de } \\
\text { Ven \& } \\
\text { Ferry } \\
\text { 1980; } \\
\text { Ruekert \& } \\
\text { Walker } \\
\text { 1987; } \\
\text { Bucklin \& } \\
\text { Sengupta } \\
\text { 1993) }\end{array}$ \\
\hline \multicolumn{4}{|c|}{ MANAGEMENT CHARACTERISTICS } \\
\hline Management Attitude & $\begin{array}{l}\text { Perceived importance of: } \\
\text { Product } \\
\text { Pricing } \\
\text { Promotion } \\
\text { Physical distribution } \\
\text { Channel members }\end{array}$ & $\begin{array}{l}\text { 7-point scale } \\
1=\text { very important } \\
4=\text { moderately important } \\
7=\text { Not at all important }\end{array}$ & $\begin{array}{l}\text { Adapted: } \\
\text { (Bodur } \\
\text { 1994) }\end{array}$ \\
\hline Management experience & $\begin{array}{l}\text { Your firms' managerial experience with } \\
\text { cooperation } \\
\text { Partner firms managerial experience } \\
\text { with cooperation }\end{array}$ & $\begin{array}{l}\text { 7-point scale } \\
\text { 1=Little } \\
\text { 4=Moderate } \\
\text { 7=Considerable }\end{array}$ & Original \\
\hline $\begin{array}{l}\text { Management Perceptions/ } \\
\text { Attitudinal commitment }\end{array}$ & $\begin{array}{l}\text { To what extent do you agree with: } \\
\text { We only focus on investments with high } \\
\text { risks and returns } \\
\text { Only respond to opportunities } \\
\text { Constantly seek to introduce new } \\
\text { brands/products } \\
\text { Cooperative relationships are not } \\
\text { sufficiently profitable } \\
\text { Cooperative relationships considered } \\
\text { only when all avenue have been }\end{array}$ & $\begin{array}{l}7 \text {-point scale } \\
1=\text { Strongly agree } \\
4=\text { Agree } \\
7=\text { Strongly disagree }\end{array}$ & $\begin{array}{l}\text { Adapted: } \\
\text { (Wilkinso } \\
\text { n \& } \\
\text { Barrett } \\
\text { 1987; } \\
\text { Evangelist } \\
\text { a 1994; } \\
\text { Cavusgil } \\
\text { \& Zou }\end{array}$ \\
\hline
\end{tabular}


exhausted

Don't know enough about procedures

Our Firm is too small to be involved in

cooperative procedures

\section{INDUSTRY CHARACTERISTICS}

\begin{tabular}{|c|c|c|c|}
\hline Pace of Entry Requirements & $\begin{array}{l}\text { In terms of entry requirements in place, } \\
\text { these are: }\end{array}$ & $\begin{array}{l}7 \text { - point scale } \\
1=\text { Low } \\
4=\text { Moderate } \\
7=\text { High }\end{array}$ & Original \\
\hline Competitive Intensity & $\begin{array}{l}\text { Importance of price cutting } \\
\text { Competitiveness of market } \\
\text { Number of companies dominating the } \\
\text { market }\end{array}$ & $\begin{array}{l}\text { 7-point } \\
\text { 1= Low } \\
\text { 4= Moderate } \\
\text { 7= High }\end{array}$ & $\begin{array}{l}\text { (McGuinn } \\
\text { ess \& } \\
\text { Little } \\
\text { 1981) }\end{array}$ \\
\hline Technology Intensity & Industry technology is: & $\begin{array}{l}\text { Categorical } \\
1=\text { Old line } \\
2=\text { Medium line } \\
3=\text { High-technology }\end{array}$ & $\begin{array}{l}\text { (Cavusgil } \\
\& \\
\text { Kirpalani } \\
\text { 1993) }\end{array}$ \\
\hline Environmental Capacity & $\begin{array}{l}\text { Potential for economic growth in the } \\
\text { market } \\
\text { Current demand for your product/ } \\
\text { service/ brand } \\
\text { Potential demand for your product/ } \\
\text { service/ brand }\end{array}$ & $\begin{array}{l}\text { 7-point scale } \\
\text { 1= very unfavourable } \\
4=\text { favourable } \\
7=\text { very favourable }\end{array}$ & $\begin{array}{l}\text { (Aldrich } \\
\text { 1979) }\end{array}$ \\
\hline
\end{tabular}

Proximity

Infrastructure

$$
\text { REGIONAL CHARACTERISTICS }
$$

In relation to the location of

participating parties, they are:

Located in the same metropolitan area

Located in different metropolitan areas

Located in the same regional area

Located in different regional area

How would you rate the following aspects of infrastructure between the participating parties

Transportation links

Telecommunication links

Overall infrastructure

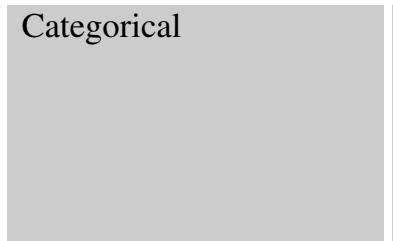

7-point scale

$1=$ low

$4=$ moderate

$7=$ high

Original

(Styles \&

Ambler

1997)

\section{CO-MARKETING ALLIANCE STRATEGIES}

$\begin{array}{ll}\text { Co-product Strategy } & \text { Do you cooperate based } \\ \text { Cooperative product de } & \text { Product bundling } \\ \text { Cooperative packaging } & \text { Cooperative labelling } \\ \text { Cooperative Branding }\end{array}$

Co-promotion Strategy
Do you cooperate based on:

Cooperative advertising

Cooperative sale promotion

Cooperative trade show displays

Cooperative events management 7-point scale

Original

$1=$ low cooperation

$4=$ moderate cooperation

$7=$ substantial cooperation

7-point scale
1= low cooperation
$4=$ moderate cooperation
$7=$ substantial
cooperation

Original 


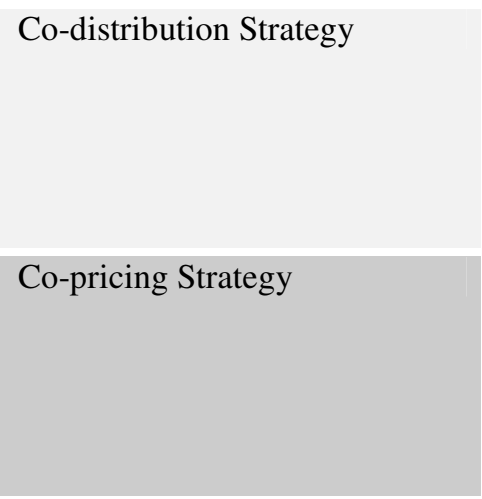

Do you cooperate based on: Cooperative distribution intermediaries Cooperative transportation

Cooperative warehousing

Cooperative inventory control

Do you cooperate based on:

Pricing

Packaged pricing 7-point scale

$1=$ low cooperation

$4=$ moderate cooperation

$7=$ substantial

cooperation

7-point scale

$1=$ low cooperation

$4=$ moderate cooperation

$7=$ substantial

cooperation
Original

Original

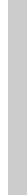




\section{Appendix II Principal Components Factor Analysis}

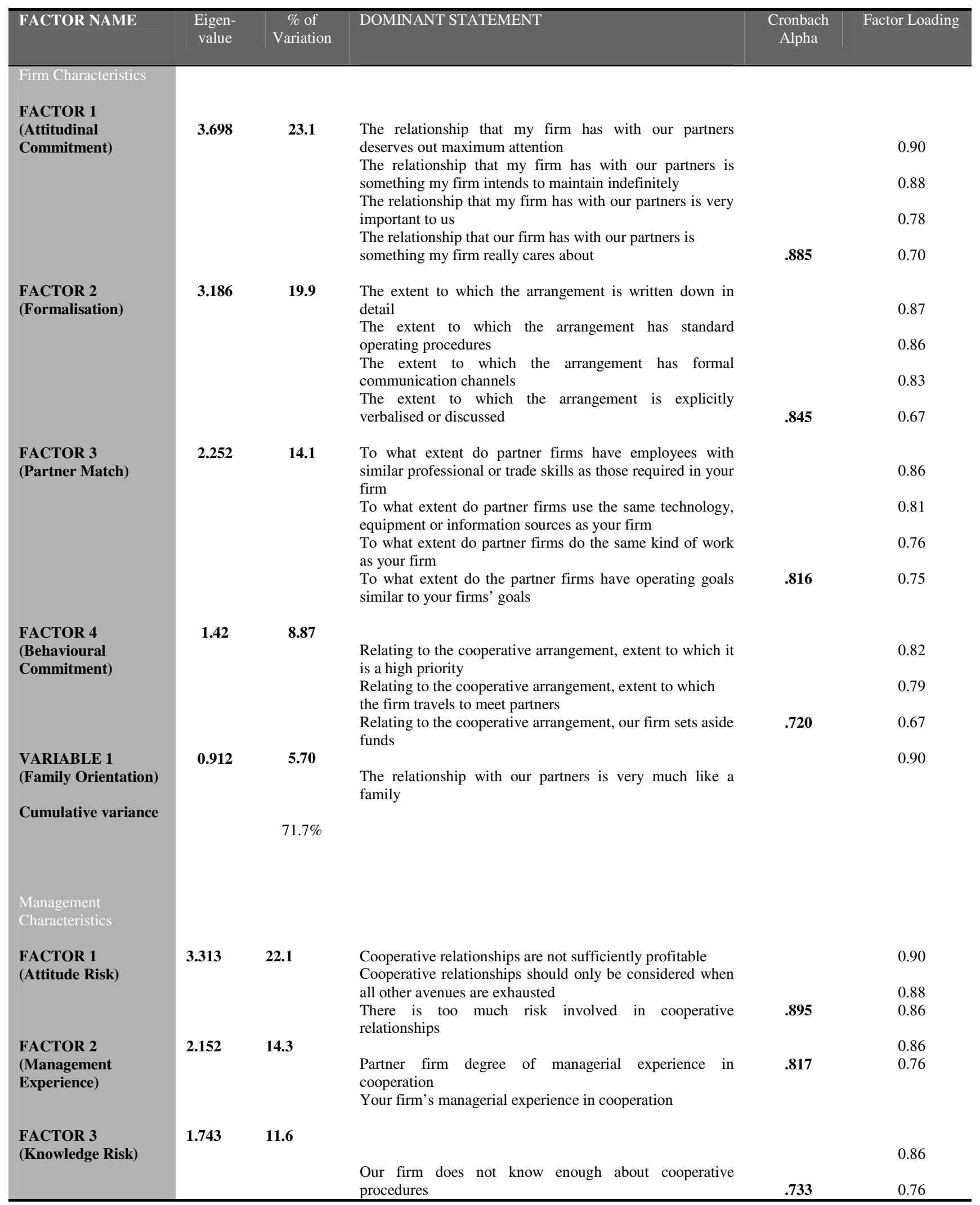




\begin{tabular}{|c|c|c|c|c|c|}
\hline $\begin{array}{l}\text { FACTOR 4 } \\
\text { (Product } \\
\text { Importance) }\end{array}$ & 1.399 & 9.33 & $\begin{array}{l}\text { Our firm is too small to be involved in cooperative } \\
\text { procedures } \\
\text { Importance of product } \\
\text { Importance of channel distribution }\end{array}$ & .710 & $\begin{array}{l}0.81 \\
0.68\end{array}$ \\
\hline $\begin{array}{l}\text { FACTOR } 5 \\
\text { (Pricing/Distribution } \\
\text { Importance) }\end{array}$ & 1.022 & 6.82 & & .721 & $\begin{array}{l}0.92 \\
0.60\end{array}$ \\
\hline $\begin{array}{l}\text { VARIABLE } 1 \\
\text { (Promotion } \\
\text { Importance) }\end{array}$ & 0.882 & 5.88 & $\begin{array}{l}\text { Importance of pricing } \\
\text { Importance of physical distribution } \\
\text { Importance of promotion }\end{array}$ & & 0.89 \\
\hline $\begin{array}{l}\text { VARIABLE } 2 \\
\text { (Proactive) }\end{array}$ & 0.861 & 5.74 & & & 0.94 \\
\hline $\begin{array}{l}\text { VARIABLE } 3 \\
\text { (Branding } \\
\text { Importance) }\end{array}$ & 0.702 & 4.68 & $\begin{array}{l}\text { Extent to which the company responds to signals of } \\
\text { opportunities quickly } \\
\text { Importance of branding }\end{array}$ & & 0.76 \\
\hline $\begin{array}{l}\text { Cumulative Variance } \\
\text { Industry } \\
\text { Characteristics }\end{array}$ & & $80.5 \%$ & & & \\
\hline $\begin{array}{l}\text { FACTOR 1 } \\
\text { (Competition } \\
\text { intensity) }\end{array}$ & N/A & N/A & $\begin{array}{l}\text { Rate the industry on price cutting } \\
\text { Rate the industry on competitiveness }\end{array}$ & .700 & 1.00 \\
\hline $\begin{array}{l}\text { FACTOR 2 } \\
\text { (Entry } \\
\text { Requirements) }\end{array}$ & N/A & N/A & $\begin{array}{l}\text { In relation to the cooperative product/service, rate the entry } \\
\text { requirements }\end{array}$ & & 1.00 \\
\hline $\begin{array}{l}\text { FACTOR 3 } \\
\text { (Environmental } \\
\text { Capacity) }\end{array}$ & N/A & N/A & $\begin{array}{l}\text { Potential for economic growth } \\
\text { Current demand for the product/service } \\
\text { Potential demand for the product/service }\end{array}$ & .795 & 1.00 \\
\hline $\begin{array}{l}\text { Regional } \\
\text { Characteristics }\end{array}$ & & & & & \\
\hline $\begin{array}{l}\text { FACTOR 1 } \\
\text { (Infrastructure) }\end{array}$ & 2.149 & 71.63 & $\begin{array}{l}\text { Rate the linkages between partners in terms of overall } \\
\text { infrastructure linkages } \\
\text { Rate the linkages between partners in terms of } \\
\text { telecommunication linkages } \\
\begin{array}{l}\text { Rate the linkages between partners in terms of } \\
\text { transportation linkages }\end{array}\end{array}$ & .793 & $\begin{array}{l}0.91 \\
0.82 \\
0.80\end{array}$ \\
\hline $\begin{array}{l}\text { Marketing Strategies } \\
\text { FACTOR 1 } \\
\text { (Co-distribution) }\end{array}$ & 5.280 & 44.00 & $\begin{array}{l}\text { Extent of cooperation in transportation } \\
\text { Extent of cooperation in inventory control } \\
\text { Extent of cooperation in distribution intermediaries } \\
\text { Extent of cooperation in packaging }\end{array}$ & .803 & $\begin{array}{l}0.86 \\
0.76 \\
0.57 \\
0.53\end{array}$ \\
\hline $\begin{array}{l}\text { FACTOR } 2 \\
\text { (Co-promotion) }\end{array}$ & 1.514 & 12.62 & $\begin{array}{l}\text { Extent of cooperation in events management } \\
\text { Extent of cooperation in trade show displays } \\
\text { Extent of cooperation in advertising }\end{array}$ & .726 & $\begin{array}{l}0.83 \\
0.74 \\
0.54\end{array}$ \\
\hline $\begin{array}{l}\text { FACTOR } 3 \\
\text { (Co-product ) }\end{array}$ & 1.111 & 9.259 & $\begin{array}{l}\text { Extent of cooperation in service bundling } \\
\text { Extent of cooperation in product bundling } \\
\text { Extent of cooperation in new product development } \\
\text { Extent of cooperation in pricing }\end{array}$ & .779 & $\begin{array}{l}0.98 \\
0.73 \\
0.54 \\
0.54\end{array}$ \\
\hline $\begin{array}{l}\text { FACTOR } 4 \\
\text { (Co-branding) }\end{array}$ & 0.878 & 7.318 & Extent of cooperative branding & & 0.84 \\
\hline $\begin{array}{l}\text { Cumulative Variance } \\
\text { Performance } \\
\text { Outcomes }\end{array}$ & & $73.2 \%$ & & & \\
\hline
\end{tabular}




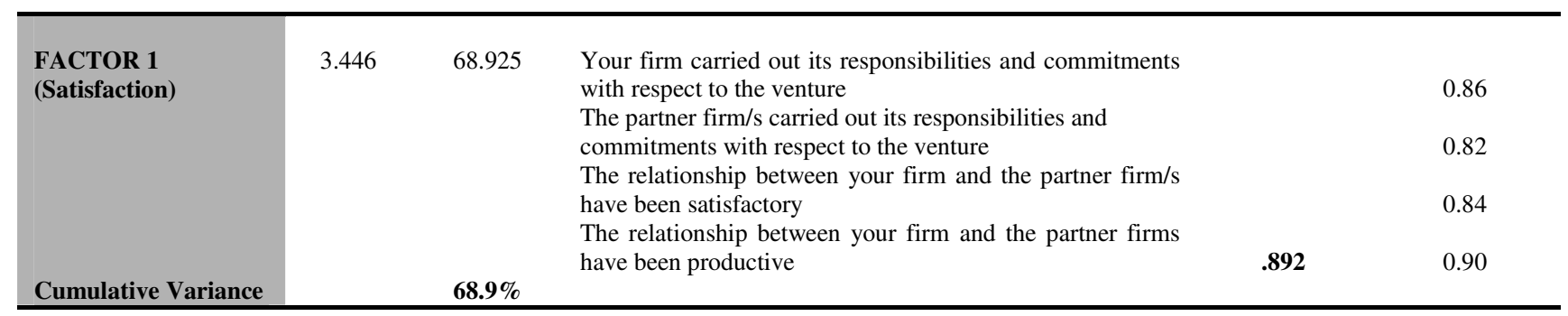




\section{Figure I $\quad$ Research Model}

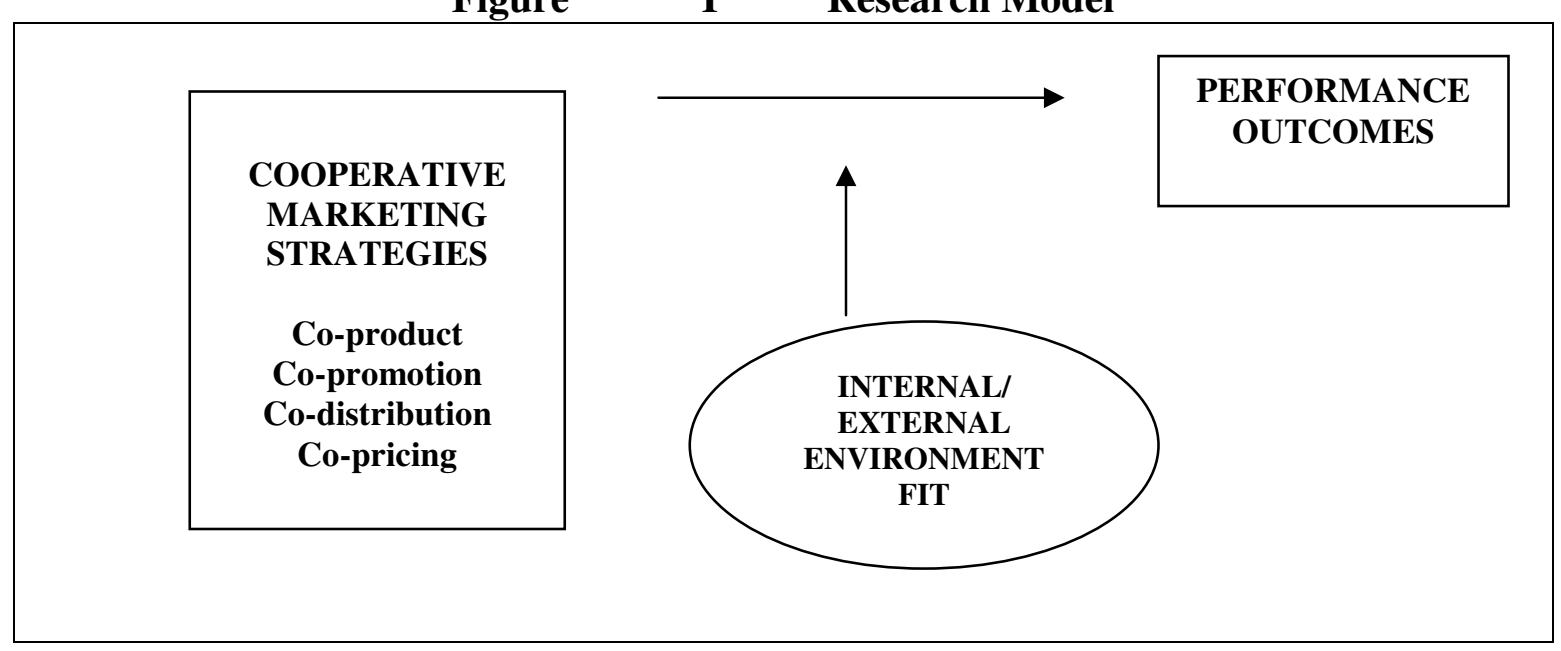


Table I Independent t-test: Relationship between Co-Marketing \& Performance for New Factors

\begin{tabular}{|llclcc|}
\hline FACTOR & \multicolumn{2}{l}{ Low Performance } & \multicolumn{2}{l|}{ High Performance } & Significance* \\
\hline \hline & Mean & SD & Mean & SD & \\
COMARKETING & & & & & \\
STRATEGY & & & & & .96 \\
Co-distribution & 3.5 & 1.64 & 4.0 & 1.96 & $.039^{*}$ \\
Co-promotion & 3.5 & 1.67 & 4.5 & 1.99 & $.001 *$ \\
Co-product & 4.2 & 1.49 & 4.9 & 1.54 & $.001 *$ \\
Co-branding & 3.8 & $\mathbf{1 . 9 4}$ & 4.7 & $\mathbf{2 . 3}$ & $.010^{*}$ \\
\hline
\end{tabular}

*Significant at $95 \%$ confidence interval 
Table II Multivariate statistics discriminating Performance Cluster Membership Entering Canonical Functions for Discriminant Analysis

\begin{tabular}{l|c}
\hline Significant Discriminant Variables & Wilks Lambda \\
\hline Regional Infrastructure & .438 \\
Entry Requirements & .310 \\
Environmental Capacity & .205 \\
Competitive Intensity & .172 \\
\hline
\end{tabular}


Table III Mean predictor scores across significant indicators

\begin{tabular}{lccc}
\hline \multicolumn{1}{c}{ Variable } & $\begin{array}{c}\text { Mean Predictor Scores } \\
\text { Cluster 1 } \\
\text { Moderate } \\
\text { Cooperation }\end{array}$ & $\begin{array}{c}\text { Cluster 2 } \\
\text { High } \\
\text { Cooperation }\end{array}$ & $\begin{array}{c}\text { Cluster 3 } \\
\text { Low } \\
\text { Cooperation }\end{array}$ \\
Competitive Intensity & 4.18 & 5.52 & 4.54 \\
Environmental Capacity & 4.87 & 5.82 & 4.71 \\
Entry Requirements & 3.63 & 5.7 & 4.04 \\
Regional Infrastructure & 0.55 & .0 .48 & -1.06 \\
\hline
\end{tabular}

